\title{
The Dominance of Oil Investment and Food Security in Nigeria under the President Obasanjo Civilian Administration
}

\author{
Ignatius E Ukwaba Ph.D \\ Department of Political Science, University of Nigeria \\ eukwaba@yahoo.com \\ Raymond Adibe \\ Department of Political Science, University of Nigeria \\ raymondadibe@yahoo.com
}

\section{Doi:10.5901/mjss.2014.v5n9p515}

\begin{abstract}
Prior to Nigeria's independence in 1960, agriculture was the main stay and dominant sector of the economy. It contributed about 70 percent of Gross Domestic Product (GDP), employed about the same percentage of the working population, and accounted for about 90 percent of foreign earnings and Federal Government revenue. However, with the discovery of oil in commercial quantity at Oloibiri in the Niger Delta in 1956, the country's fortunes have depended on the Oil Industry, which has effectively replaced agriculture in revenue yield. In fiscal terms, oil revenue currently account for about 80 percent of government revenues, 95 percent of export receipts and 90 percent of foreign exchange earnings. This work investigated the link between the dominance of oil investment and food security in Nigeria under the Obasanjo civilian administration. While observing that agriculture had in the past contributed to national prosperity and food security, it was noted that discovery and commercial exploitation of oil resources in Nigeria fundamentally changed the structure of investment in Nigeria resulting in the dominance of foreign capital not only in the Oil Industry, but also in the Nigerian economy. The work clearly demonstrated that the dominance of oil investment in Nigeria not only undermined linkage with other sectors between 1999 and 2007, it is implicated in her food security crisis.
\end{abstract}

Keywords: Oil Dependence, Rentier State, Food security, Oil Capital, Agro Investment

\section{Introduction}

The massive increase in oil revenue as an aftermath of the Middle -East war of 1973 created unprecedented, unexpected and unplanned wealth for Nigeria. The paradox however, is that despite the huge resources from oil, Nigeria is characterized by threat of hunger, about 70 percent of the population lives on less than $N 400$ (\$ 0.7) per day, youth unemployment and food imports have been on the increase. More so, hunger and malnutrition continue to plague the Nigerian economy. For instance, during the period of 1970 - 1979, the average annual deficit in per capita daily calories intake was 24.4 percent. It declined to 23.58 percent within 1980 - 1989 and by 2006; it reached a nadir 11.34 percent (CBN, 1993; African Development Bank, 2007). This problem has been a recurring issue and the World Bank, and recent reports show that about 90 million Nigerians or about 40 percent of the population suffer from food insecurity. Consequently, the incomes of most families are not adequate for the basic sustenance of life (Akpan, 2009). On the whole, Nigeria has been a disastrous development experience. On just every conceivable metric, Nigeria's performance since independence has been dismal. In PPP terms, Nigeria's per capita GDP was US \$1,133 in 1970 and as at 2006, remained at US \$1,084 implying a decrease. The latter figure places Nigeria amongst the 15 poorest nations in the world for which such data are available (World Bank's WDI, 2007).

Food security is the accessibility of all people, at all times, to enough food for an active and healthy life (Reutlinger, 1987). Food security has two aspects; ensuring that adequate food supplies are available, and that households whose members suffer from under-nutrition have the ability to acquire food, either by producing it themselves or by being able to purchase it (Riscopoulos et al, 1988). Most countries with food security problems are assessed based on three indicators; low average levels of calorie consumption, large fluctuations in and low levels of food consumption, and large numbers of absolute poor (Brown et al, 1992). In light of this, Nigeria is considered a food insecure country with an alarming poverty rate of about 70 percent as well as a recurring deficit in the percentage of per calories intake (FAO Statistics, 2007) and a 
massive rate of food importation in the country which is estimated at US $\$ 3$ billion yearly (Anuforo, 2009). The above situation is worrisome when we consider the fact that since the first oil shock in 1974, oil has annually produced over 90 percent of Nigeria's export income and with the second oil boom of the 2000s, the country for instance received 99.6 percent of its export income from oil in 2000 making it the world's most oil dependent country (Akpan, 2009). This invariably implies that the excess wealth gotten from oil exploitation has not transformed the socio-economic fortune of the nation both in terms of physical and human development. The Ministry of Agriculture for instance has estimated that $65 \%$ of the population is food insecure. The proportion of children aged under- five who are underweight has fallen only slightly from 36\% in 1990 to 29\% in 2005 and about half of the country's available land lies fallow which has made Nigeria become the world's largest importers of food, especially of wheat and rice, whereas, it has the potential for surplus.

While it is common in literature to attribute poor food security statistics in Nigeria to government's neglect of the agricultural sector arising from the discovery and commercial exploration of oil, such arguments tend to neglect governmental efforts in rescuing the situation through intervention programmes and policies. For instance, Morgues et al (2002) noted as much as 179 agricultural programmes have existed in Nigeria. Also, Akpan (2009) noted that under President Obasanjo first term as civilian President, as much as four food security programmes and policies were initiated and implemented. Existing literature is yet to give systematic analysis to the pattern of investment in the nation's economy. The need to understand the pattern of investment in Nigeria particularly oil investment is crucial since oil capital constitute the bulk of investment capital in Nigeria. Hence, there is need to understand how such investments has encouraged and influenced pattern of government spending in the sectors of the economy. Hence, this work investigated the dominance of oil investment and food security in Nigeria under the Obansanjo civilian administration.

\section{Theoretical Framework}

The link between the dominance of oil investment and food security in Nigeria is explained using the theory of the rentier state as our framework of analysis. The theory of the rentier state is a complex of associated ideas concerning the patterns of development and the nature of states in economies dominated by external rent, particularly oil rent (Yates, 1996). The concept of the "rentier state" was postulated by Hossein Mahdavy with respect to pre-revolutionary Pahlavi Iran in 1970. The idea of the rentier state assumed new importance in the decades following Mahdavy's work. His ideas experienced a kind of renaissance in the 1980s in the literature of scholars like Beblawi and Luciani (1987) who were interested in the impact of oil windfall on the nature of Arab States. According to this theory, four characteristics must be present in order for a state to be classified as rentier. First, the rentier economy of which the state is a subset must be one where rent situations predominate. Second, the origin of the rent must be external to the economy. In other words, the rent must come from foreign sources. Domestic rent, even if it were substantial enough to predominate is not sufficient to characterize such economy as rentier. Third, in a rentier state, only the few are engaged in the generations of rents, while majority are involved in the distribution and consumption. Therefore, an open economy with high levels of foreign trade is not rentier, even if it depends predominantly on rent (e.g. agriculture), because majority of the society is actively involved in the creation of wealth. Finally, the government must be the principal recipient of the external rent in the economy.

The implication of the above is that external rent liberates the state from the need to extract income from the domestic economy. Thus, unlike a 'production state' that relies on taxation of the domestic economy for its income and in which economic growth is therefore, an imperative - an 'allocation state' like Nigeria does not depend on domestic sources of revenue but rather is the primary source of revenue itself in the domestic economy. The theory of the rentier state postulates that there is a lackluster attitude prevalent among rentier states to their conditions of socio-economic and technological backwardness (Yates, 1996). This arise from the ability of the rentier state to use their huge foreign earnings to purchase 'welfare and prosperity' from outside. Thus, in Nigeria, instead of attending to the task of expediting the basic socio-economic transformations, the rentier elites' ability to embark on massive spending and consumption preempts some of the urgency for change-and rapid growth. Hence, Nigeria's government response to the issue of food insecurity is one that favours massive importation of food which is now estimated at US \$ 3billion annually rather than a transformation of the agricultural sector, so as to increase its capacity to cater for domestic food needs and establish inter-sectoral linkages with other sectors of the economy.

The economic behavior of a rentier is distinguished from conventional economic behavior in that it embodies a break in the work-reward causation (Beblawi and Lucian, 1987). As noted by Yates (1996), rewards of income and wealth for the rentier do not come as the result of work, but rather are the result of chance or situation. That is, income and wealth are seen as situational or accidental rather than as the end result of a long process of systematic and organized production. Under this situation, there is a high tendency for people to seek employment only in businesses associated 
with the booming oil sector; hence, people seek out lucrative government employment since it is government that controls most of the oil wealth of the state which has little or no linkage with other sectors. This has a serious implication on the effort of achieving food security in Nigeria since the agrarian sector which has a strong rural base is undermined by massive rural-urban migration as more able-bodied people migrate to areas where they can have access to 'white collar' jobs associated with the booming oil sector. One consequence of the large amount of external rent available in a rentier economy is that the state tends to relax constraint on foreign exchange. Thus, the availability of foreign currency in such relative abundance means that the rentier state can acquire foreign goods without the usurious costs of exchange (Yates, 1996). This also implies that imported goods have the tendency to replace domestically produced goods, particularly in agriculture and manufacturing, which often cannot compete with foreign goods produced under economies of scale. The state purchases foodstuffs, which then compete with domestically produced foodstuffs in the local markets. This affects domestic agricultural production and domestic industries may become net consumers rather than net producers of the national income. It is in this light we explained the link between the dominance of oil investment and food security in Nigeria.

\section{Oil Investment and Agricultural Output in Nigeria}

In the face of inadequate resources to finance long term development in Africa and with poverty reduction looking increasingly bleak, attracting foreign capital has assumed a prominent place in the development strategies of African countries including Nigeria. Such foreign investment capital, it's believed would bridge the gap of low income countries and avoids further build-up of debt while directly tackling the causes of poverty (UNCTAD, 2004). Current trends of foreign investments in the Nigerian economy showed that Nigeria has consistently benefited from the inflow of foreign investment capital into Africa since her return to democratic rule. Between 1999 and 2009, the cumulative foreign private investment in the Nigerian economy rose from N154, 190.4 million to N441, 271.3 million, representing almost a 400 percent increase (CBN Statistical Bulletin, Various Issues, 2009).

However, despite increased level of foreign investment in Nigeria since 1999, there has been a dominance of investment capital in the extractive sector with the share of petroleum in Foreign Direct Investment (FDI) inflows accounting for over 85 percent of total FDI in the Nigerian economy. In a sector that employs less than 2 percent of her citizens and where production is more oriented towards external consumption, the ability of such investments to have a linkage effect on other sectors of the economy particularly the agricultural sector becomes very minimal.

Table 1: Agricultural Composition FDI in Nigeria, 1999-2007

\begin{tabular}{|c|c|c|}
\hline Year & Cumulative FPI in Nigeria (N million) & Percentage of Agriculture in CFPI (\%) \\
\hline 1999 & $153,190.4$ & 0.8 \\
\hline 2000 & $157,508.6$ & 0.8 \\
\hline 2001 & $161,441.6$ & 0.7 \\
\hline 2002 & $166,631.6$ & 0.7 \\
\hline 2003 & $178,478.6$ & 0.7 \\
\hline 2004 & $249,220.6$ & 0.5 \\
\hline 2005 & $324,656.7$ & 0.5 \\
\hline 2006 & $481,239.1$ & 0.2 \\
\hline 2007 & $552,498.6$ & 0.2 \\
\hline
\end{tabular}

Source: CBN Statistical Bulletin, Various Issues, 1999-2007

This table showed that less than one percent of total FPI in the Nigerian economy between 1999 and 2007 was in the agricultural sector. In 1999, it accounted for only 0.8 percent of total FPI and reduced to 0.7 percent between 2001 and 2003. It further reduced to 0.5 percent between 2004 and 2005, and also had an all-time low of 0.2 percent in 2007. Despite the scenario, the growth rate of the Nigerian non-oil sector in 2005 stood at 8 percent, superseding the annual growth rate of the economy which stood at 7 percent (Nwankwo, 2006). Also, despite the low level of FPI in the agricultural sector, the average annual growth rate of the sector between 1999 and 2007 stood at 6 percent. Although this is below the targeted 10 percent annual growth rate required to eradicate poverty and hunger through self sufficiency in food production, the performance of the agricultural sector in comparison with that of the oil sector when we consider the level of investment in both sectors become an indication that with more capital investment in the agricultural sector, achieving food security in terms of self-sufficiency in food production can become a reality. 
Table 2: Value of Major Food Imports (N million)

\begin{tabular}{|c|c|c|c|c|}
\hline Year & Food and live Animal & Beverages & Animal vegetable and Fats & Total \\
\hline 1999 & $103,489.8$ & $4,312.1$ & $12,073.8$ & $119,875.7$ \\
\hline 2000 & $113,630.5$ & $6,740.8$ & $12,444.6$ & $134,815.9$ \\
\hline 2001 & $160,209.1$ & $9,503.9$ & $20,365.6$ & 210444.2 \\
\hline 2002 & $144,297.6$ & $12,670.8$ & $21,279.4$ & $179,247.8$ \\
\hline 2003 & $201,648.3$ & $18,830.1$ & $34,185.8$ & $254,664.2$ \\
\hline 2004 & 178,7474 & $21,846.7$ & $39,307.6$ & $239,901.7$ \\
\hline 2005 & $193,259.1$ & $28,008.6$ & $70,021.4$ & $291,289.1$ \\
\hline 2006 & $217,603.02$ & $31,536.70$ & $78,841.73$ & 327,98145 \\
\hline 2007 & $247,603.02$ & $39,848.88$ & $87,667.55$ & $374,579.5$ \\
\hline
\end{tabular}

Source: CBN Statistical Bulletin, Various Issues, 1999-2007

Food importation, which is an indication of domestic food shortfall, has been on the increase in Nigeria since 1999. From the above table, total value of major food imports between 1999 and 2007 witnessed about 300 percent increase. This shows that domestic food production in Nigeria is not growing at the same pace with domestic food demand, thereby necessitating food importation to cover for the shortage. In fact the 2008 FAO data on food security situation in Nigeria showed that there was a decline in agricultural production of certain major staple food in the country between 2000 and 2007 as well as an increase in their import within the same period. For instance, while rice production fell from 4,042,000 MT in 2006 to 3,186,000MT in 2007, rice importation within the same period rose from 975,911MT to 1,216,967MT. Also, while wheat production declined from 71,000 MT to 44,000MT between 2006 and 2007, its import value rose to $7,795,100 \mathrm{MT}$ from 3,244,000MT within the same period (FAO, 2008).

Table 3: Nigeria's Food Shortfall (Million Mt) and Import (\#billion), 2001-2007

\begin{tabular}{|l|c|c|c|c|c|c|c|}
\hline Year & 2001 & 2002 & 2003 & 2004 & 2005 & 2006 & 2007 \\
\hline Shortfall (Deficit) & 0.53 & 0.30 & 2.91 & 3.34 & 3.13 & 4.22 & 5.34 \\
\hline Food import & 16.77 & 88.35 & 75.95 & 100.6 & 102.16 & 103.49 & 120.05 \\
\hline
\end{tabular}

Source: CBN Statistical Bulletin, Various Issues, 2001-2007

The above table shows that food production has not been able to match food demand creating food shortfall on yearly basis. From a deficit of 0.53 in 2001, it rose to 5.34 in 2007 which represents over 500 percent increase in food shortfall. Also, from N16.77billion in 2001, food importation in Nigeria was continuously on the increase and by the end of 2007, it stood at N120.05 billion. As noted earlier, the performance of the agricultural sector despite the dominance of oil investment and capital in the Nigerian economy is a clear indication that the sector has the capacity to make Nigeria a food secured nation in terms of self-sufficiency in food production to meet her citizens' food demand as well as produce surplus for export. However, the dominance of oil capital, coupled with the rentier character of managing oil resource makes it difficult for such oil investment to have a linkage effect with the agricultural sector or other sectors of the economy. This situation results in capital flight or a negative net-foreign investment flow since less than 2 percent of the country's workforce are engaged in oil production.

\section{The Structure of Oil Income and Food Security Indicators in Nigeria}

The structure of oil income in Nigeria is centralized with the Federal Government as the sole rent collector. The rentier management of oil resource also means that the Nigerian economy is not immune from the problems associated with rentier economies. It has been established earlier in this work that oil management is rentier in character. It accounted for 83.5 percent of total government revenue in 2000, 85.6 percent in 2004, 85.8 in 2005, 88.6 percent in 2006, 83 percent in 2008 and 78.7 percent in 2009 (CBN Statistical Bulletin for Various Years). Also, as noted by Eboh (2011), the oil sector accounts for less than four (4) percent of the total employment in Nigeria and oil production is oriented towards external consumption. 
Table 4: Summary of Federal Government Revenue, 1999-2007

\begin{tabular}{|c|c|c|c|c|}
\hline Year & Oil Export & Non-oil Export & Total Export & \% of oil Export \\
\hline 1999 & $949,187.90$ & $724,422.50$ & $224,756.40$ & 76.3 \\
\hline 2000 & $1,906,159.70$ & $1,591,675.80$ & $314,483.90$ & 83.5 \\
\hline 2001 & $2,231,532.90$ & $1,707,562.80$ & $523,970.10$ & 76.5 \\
\hline 2002 & $1,731,837.50$ & $1,230,851.20$ & $500,986.30$ & 71.1 \\
\hline 2003 & $2,575,095.90$ & $2,074,280.60$ & $500,815.30$ & 80.6 \\
\hline 2004 & $3,920,500.00$ & $3,354,800.00$ & $565,700.00$ & 85.8 \\
\hline 2005 & $5,547,500.00$ & $4,762,400.00$ & $785,100.00$ & 85.8 \\
\hline 2006 & $5,965,101.90$ & $5,287,566.90$ & $677,535.00$ & 86.6 \\
\hline 2007 & $5,715,500.00$ & $4,462,950.00$ & $1,252,550.00$ & 78.1 \\
\hline
\end{tabular}

Source: CBN Statistical Bulletin, Various issues, 1999-2007

The above scenario results in a mono-cultural outlook of the Nigerian economy which makes it vulnerable to external shock in the global economy. Since the Nigerian economy survives on this external rent, any event that disrupts or affects the flow of the rent, in turn, affects the government. Hence, public spending capacity is a function of oil rent capacity. There's a poor sectoral linkage of the oil sector to other sectors of the economy as a result of the distortion associated with the external orientation of consumption of oil resource. The implication of this is that most of the seemingly huge revenue gotten from oil is spent in acquiring finished goods that cannot be produced domestically and whose prices fluctuates with changes in international price of oil: In the Nigerian situation, this is evident in the continuous increasing value of her import. In 1999, Nigeria's non-oil import was N1, 121,073.5 million, but it rose to N1, 668,930.6 million in 2004 and N2, 003,557.4 million in 2005. By the end of 2009, the value rose to N3,958,617.8 million giving Nigeria a negative balance of trade for non-oil commodities worth N3,669,465.2 (CBN Statistical Bulletin, Various Issues, 2009). The structure of oil income in Nigeria which is marred by fluctuations and external shocks as well as the rentier management of the oil rent by the Federal Government undermines government investment in food production. Between 1999 and 2007, public sector expenditure in agriculture remained unstable, wrongly skewed and grossly inadequate. As noted by Eboh (2011), agricultural sector contributed an annual average of more than 32 percent of GDP from 2002 to 2007, but its share of total federal government spending within this period averaged 4.3percent. He further noted that agriculture sector share of total state governments spending from 2002 to 2007 averaged 3.6 percent. Agriculture sector share of federal and state government's spending from 2002 to 2007 averaged 3.4 percent and the ratio of agriculture sector spending to agricultural sector GDP averaged 2.8 percent from 2002 to 2007 (Eboh, 2011). In fact, the long-term average of the ratio of agricultural sector expenditure share of GDP to agricultural sector share of GDP is about 0.07, indicating that agriculture sector spending has been less than one-tenth of agricultural sector share of the GDP (Eboh, 2011).

These appalling indicators show that agriculture sector spending has been inconsistent with agriculture sector contribution to (and status in) the national economy. Public sector expenditure on the agricultural sector has been fraught with high degree of volatility or fluctuations from year to year. There is a huge financing gap in Nigeria's agriculture. As noted by Eboh (2011), projected Federal Government funding for agriculture and food security over a four year period 2008-2011 is about N 935 billion, but total federal budget for agriculture and water resources in 2008 was less than N120 billion, as against the projected finding needs of about N 319 billion for 2008. Apart from being too meager, public spending in agriculture between 1999 and 2009 has been wrongly skewed. Fertilizer subsidy consumes about 42 percent; food security programmes gulp about 22percent, while strategic grain reserve programmes (e.g. storage facilities, grain purchases) take about 16 percent. Very marginal portion of the total capital spending is applied to research and extension (Eboh, 2011). Evidences are bound to support our argument that the dominance of oil investment in Nigeria's economy worsened her food security crisis under the Obasanjo civilian administration. Food security as noted earlier imply access, at all times to adequate, safe, nutritious and healthy food that meets day to day nutrient requirements. Unfortunately, Nigeria fared badly on almost every indicators of food security between 1999 and 2007, particularly on food accessibility. 
Table 5: Food Deprivation and Consumption Indicators in Nigeria, 1990-2007

\begin{tabular}{|l|c|c|c|}
\hline Year & $\begin{array}{c}\text { Food Deficit of } \\
\text { Undernourished Population } \\
\text { (Kcal/Person/Day) }\end{array}$ & $\begin{array}{c}\text { Minimum Dietary Energy } \\
\text { Requirement (MDER) } \\
\text { (Kcal/Person/Day) }\end{array}$ & $\begin{array}{c}\text { Animal Protein } \\
\text { Consumption } \\
\text { (g/person/Day) }\end{array}$ \\
\hline $1990-1992$ & 220 & 1710 & 6.8 \\
\hline $1995-1997$ & 200 & 1720 & 6.9 \\
\hline $2000-2002$ & 200 & 1720 & 7.6 \\
\hline $2003-2004$ & 200 & 1720 & 7.6 \\
\hline $2005-2007$ & 180 & 1730 & 7.9 \\
\hline
\end{tabular}

Source: FAO 2008, Nigeria's Food Security Indicators

The United Nations recommendation on food consumption for developing nations is a minimum intake of 2718 calories per capita from livestock products. Also, the required animal protein intake for developing nations is IOgramme per capita per day. However, from the above table, we can see that Nigeria fell short of the requirements in the period under review. Animal protein consumption stood at 6.8g/person/day between 1990 and 1992, and between 2000 and 2007, it still fell below the required minimum, fluctuating between $7.6 \mathrm{~g} /$ person/day and $7.9 \mathrm{~g} /$ person/day. Also, food deficit of undernourished population between 1999 and 2007 consistently remained at $200 \mathrm{Kcal} /$ person/day for almost a decade. This situation shows that more and more people are lacking access to food in Nigeria when we consider government food import receipts in Nigeria under the same period. Although, the Nigerian government between 1999 and 2007 relied on food importation to supplement domestic food demand shortfall, certain economic indices still show that food accessibility was a problem. One of such indicators is the nation's poverty rate

Table 6: Nigeria's Poverty Rate, 2000-2007

\begin{tabular}{|l|c|c|c|c|c|c|c|c|}
\hline Year & 2000 & 2001 & 2002 & 2003 & 2004 & 2005 & 2006 & 2007 \\
\hline (a)Estimated Population (In million) & 109.3 & 111.3 & 114.0 & 116.4 & 120 & 126.2 & 131 & 148 \\
\hline (b)\% below poverty rate & 34.1 & 45 & 45 & 60 & 60 & 60 & 60 & 60 \\
\hline
\end{tabular}

Source: (a) National Population Commission (NPC), 2008; (b) Federal Bureau of Statistics, 2008

From the table above, Nigeria's poverty rate continuously rose between 2000 and 2007 despite her huge earnings from oil resources within the same period. The section on poverty rate showed a steady increase in the population living below the poverty line. The implication of this on food security is not farfetched. The Ministry of Agriculture has estimated that 65 percent of the population is food insecure. The proportion of children aged under- five who are underweight has fallen only slightly from 36 percent in 1990 to 29 percent in 2005. While Nigeria's per capita income in the pre-oil era stood at an average of over US\$400, between 1999 and 2007, it reduced to an average of less than US\$ 265 (ADB, 2003; ljaiya, 2007). Also, FAO statistics on Nigeria in 2009 rates the country 17.8 in global hunger index. It also showed that 27 percent of children in Nigeria between 2003 and 2009 were undernourished and under -5 mortality rate per 1,000 in 2009 stood at 212, all of which are indications of worsening food accessibility in the country.

The link between the dominance of oil investment and food insecurity in Nigeria is well established in this work. As a result of its excess oil revenue, government tends to relax its attention on other sectors (agriculture inclusive) as a source of revenue generation. This is manifested in declining investment in the agricultural sector of the economy, a situation which reduces production in the sector and shifts citizen attention to only sectors associated with oil rents, particularly the public sector. This is also evident in the increasing rural to urban migration in Nigeria where more and more able- bodied men and women migrate to the cities in search of 'white collar jobs' associated with the booming oil sector. With lesser number of the population involved in agriculture and in particular, food production, output declines and with demand rising above supply, the tendency for food items' prices to increase above citizen's income becomes inevitable.

\section{Conclusion}

The study attempted to demonstrate whether the dominance of oil investment in Nigeria is implicated in her food security 
crisis and it revealed that the meager concentration of foreign investment in the agricultural sector as well as the alienation of most Nigerians from skilled employment in the oil sector undermines positive sectoral linkage of oil and agricultural sectors of the economy. Also, production boosting technological transfer associated with foreign investment is missing in the agricultural sector with insufficient capital to embark on large agricultural production and agro-research. Thus, food accessibility in Nigeria between 1999 and 2007 was undermined. FAO statistics on food security indicators as well as poverty rate in the country within the same period were presented as evidence of food security challenges in Nigeria. In the light of this finding, the following recommendations were put forward for policy implementation:

- There is need to decentralize the management and collection of oil rent in Nigeria. The Federal Government remains the sole collector of oil rent in Nigeria and less than four percent of Nigerians are employed by the oil sector. This situation not only makes accountability in the management process difficult, it also hinders effective sectoral linkage with agriculture. Hence, there is need for popular participation of the citizens in the petro economy in terms of what to produce how to produce and whom to produce for. This will not only make oil resource management accountable, it will in turn ensure proper divestment into agriculture and other sectors of the economy, thereby improving food security situation in Nigeria.

- While government funding of agriculture remains poor constituting less than two percent budgetary allocation between 1999 and 2009, we recommend that apart from the need to increase agricultural funding in Nigeria to about 10 or 15 percent of Nigeria's total budget. There is also the need to place more emphasis on agroresearch and extension. Most of government funding in agriculture goes to fertilizer subsidy and food security programmes. Such subsidies beneficiaries are majorly the small-scale farmers whose outputs remain a far cry from domestic food demand in Nigeria. Therefore funding priority should be given to capital intensive agroresearch and extension that have the capacity of boosting food production even above domestic food demand as well as produce surplus for export.

\section{References}

Africa Development Bank, Selected Statistics on Regional Member Countries, 2003

Africa Development Bank, Selected Statistics on Regional Member Countries, 2007

Anuforo, E (2009) "Nigeria's 3 billion Yearly Food Import Bill Worries UK Group, Others" Guardian Newspaper, 16th July

Apkan, E.O (2009) "Oil Price Shocks and Nigeria's Macro Economy" A Paper Presented at CSAE Conference, Oxford University, Oxford, UK, 21- 23 March

Beblawi, H and Luciani, G (1987) "The Rentier State" in H. Beblawi and G. Luciani (eds) Nation, State and Integration in the Arab World. London: Croom Helm

Braun, V et al (1992) Improving Food Security of the Poor: Concept, Policy and Programs. Washington, D.C: International Food Policy Research Institute (IFPRI)

Central Bank of Nigeria, Statistical Bulletin, Various Issues, 1993

Central Bank of Nigeria, Statistical Bulletin, Various Issues, 1999-2007

Central Bank of Nigeria, Statistical Bulletin, Various Issues, 2009

Eboh, C.E (2011) "Agricultural Economy of Nigeria: Paradoxes and Crossroads of Multimodal Nature" An Inaugural Lecture of the University of Nigeria Delivered the Princess Alexandria Auditorium. 27 January

Federal Bureau of Statistics, Annual Abstract of Statistics, 2009

Food and Agriculture Organization, Food Security Report on Nigeria, 2008

Ijaiya, G. T (2007) "Poverty Alleviation Programmes" in H. Saliu; E. Amali and R. Olawepo (eds) Nigeria's Reform Programme: Issues and Challenges. Ibadan: Vantage Publishers.

Mogues, T et al (2008) Agricultural Public Spending in Nigeria. Washington D.C: International Food Policy Research Institute (IFPRI)

National Population Commission, Annual Population Statistics, 2009

Nwankwo, A (2006) "The Determinants of FDI Inflows in Nigeria" A Paper Presented at the 6th Global Conference on Business and Economics, Gutman Conference Centre, USA. 15th - 17th October

Reuthinger, S (1987) "Food Insecurity and Poverty in Developing Countries" in J. P. Gitinger; J. Leslie and D. Huntington (eds) Food Policy. US: John Hopkins University Press

Riscopoulous, S.J et al (1988) "Agriculture in the Year 2000, The Case of the African Caribbean and Pacific Countries" International Forum, Athens. November

UNCTAD (2004) Economic Development of Africa: Rethinking the Role of Foreign Direct Investment

World Bank, World Development Indicators, 2007

Yates, D.A (1996) The Rentier State in Africa, Oil Rent, Dependency and Neocolonialism in the Republic of Gabon. Trenton, NJ: Africa World Press 